\title{
Good governance pengelolaan sampah: komitmen negara terhadap lingkungan hidup
}

\author{
Niken Wahyuning Retno Mumpuni ${ }^{1}$, Mustika Prabaningrum Kusumawati ${ }^{2}$
}

${ }^{1}$ Niken Wahyuning Retno Mumpuni; Prodi Hukum Fakultas Ekonomi dan Sosial Universitas Jenderal Achmad Yani Yogyakarta; Jl. Siliwangi, Ringroad Barat, Ambarketawang; Sleman; Yogyakarta; Indonesia. ${ }^{2}$ Mustika Prabaningrum Kusumawati; Fakultas Hukum Universitas Islam Indonesia; Jl. Taman Siswa No. 158; Yogyakarta; Indonesia.

\begin{tabular}{l}
\hline A R T I C L E I N F O \\
\hline Article history: \\
Received 2021-02-03 \\
Received in revised form \\
2021-03-19 \\
Accepted 2021-04-01 \\
\hline
\end{tabular}

Kata kunci:

Good Governance; Pengelolaan Sampah; Kebijakan.

Keywords:

Good Governance; Trash Management; Policy.

DOI: https://doi.org/10.26905/

idjch.v12i1.5725.

How to cite item:

Mumpuni, N. W. R.,

Kusumawati, M. P. (2021).

Good governance pengelolaan

sampah: komitmen negara terhadap lingkungan hidup. Jurnal Cakrawala Hukum, 12(1), 79-89. doi:10.26905/

idjch.v12i1.5725
Corresponding Author:

* Niken Wahyuning Retno Mumpuni.

E-mail address: nikenmumpuni@gmail.com.

\section{Abstrak}

Indonesia telah memiliki aturan yang mengatur hal tersebut, serta diterapkannya kebijakan pengelolaan lingkungan sesuai dengan prinsip-prinsip good governance. Kebijakan tidak akan efektif ketika pembuat kebijakan salah dalam merumuskan masalah. Oleh karena itu, perlu dikaji mengenai problematika sampah serta bagaimana implementasi dari prinsip good governance dalam menciptakan kebijakan pengelolaan sampah dan plastik sekali pakai. Melalui pendekatan yuridisnormatif penelitian ini akan menguraikan serta menganalisis permasalahan sesuai dengan ketentuan peraturan perundang-undangan yang berlaku. Selain itu ditambah dengan bahan-bahan hukum seperti study pustaka dari buku-buku literatur, makalah, artikel, jurnal, hasil penelitian dan karya ilmiah lainnya yang berhubungan dengan penelitian ini. Peta permasalahan adanya kategori sampah-sampah yang sulit untuk dikelola, salah satunya adalah sampah plastik dimana wujud sampah plastik tersebut berupa kemasan, kemudian barang sekali pakai, microbeads, sedotan, pembersih telinga, kantong plastik, polystyrene dan flexible plastik. Pentingnya peran serta masyarakat dalam pengelolaan sampah di lingkup pemerintah pusat maupun daerah, serta masyarakat juga memiliki hak untuk memberikan usul dan memberikan saran terkait dengan permasalahan sampah. Bentuk upaya menjamin keamanan setiap orang dan masyarakat serta memajukan sarana ekonomi, sosial dan bidang lainnya sesuai dengan kehendak rakyat adalah konsep good governance.

\section{Abstract}

Indonesia already has rules that govern this, and the implementation of environmental management policies in accordance with the principles of good governance. Policies will not be effective when policymakers make mistakes in formulating prob- 


\section{Jurnal Cakrawala Hukum, Volume 12 No. 1 April 2021}

ISSN PRINT 2356-4962 ISSN ONLINE 2598-6538

lems. Therefore, it is necessary to study the problem of waste and how the implementation of the principles of good governance in creating disposable waste and plastic management policies. Through a juridical-normative approach this research will describe and analyze the problem in accordance with the provisions of the applicable laws and regulations. Besides that, it is added with legal materials such as literature study from literature books, papers, articles, journals, research results and other scientific works related to this research. The problem map is the category of rubbish that is difficult to manage, one of which is plastic waste where the form of plastic waste is in the form of packaging, then disposable items, microbeads, straws, ear cleaning, plastic bags, polystyrene and flexible plastic. The importance of community participation in waste management in the scope of central and regional governments, as well as the community also has the right to make suggestions and provide advice related to waste problems. The form of efforts to ensure the security of everyone and society and to advance economic, social and other fields in accordance with the will of the people is the concept of good governance.

\section{Latar Belakang}

Berdasarkan Pasal 1 angka 1 Undang-undang Nomor 18 Tahun 2008 tentang Pengelolaan Sampah, mendefinisikan sampah adalah sisa kegiatan seharihari manusia dan/atau proses alam yang berbentuk padat. Sampah merupakan zat atau benda yang dibuang karena sudah tidak dipergunakan kembali (KBBI online). Pengertian ini memberikan penafsiran yang negatif bagi masyarakat, ketika zat atau benda yang sudah tidak dipergunakan kembali kemudian disingkirkan dan dibuang tanpa ada niatan untuk mengelola sampahnya masing-masing.

Sampah dikehidupan sekarang ini merupakan permasalahan yang sulit untuk ditangani. Tingkat konsumsi masyarakat yang tidak sebanding dengan daya tampung pembuangan akhir sampah menjadi salah satu faktor sulitnya permasalahan ini diselesaikan. Tempat Pembuangan Akhir belum sepenuhnya menjadi solusi untuk penanganan sampah, perlu adanya pengelolaan/ daur ulang sampah agar dapat dimanfaatkan kembali. (slideshare.net, 2019).

Menurut penelitian oleh Jenna Jambeck di Jurnal Science tahun 2015: Jenis sampah yang menjadi permasalahan yang tak kunjung henti adalah sampah yang dihasilkan dari rumah tangga dan sampah plastik sekali pakai. Indonesia sebagai negara penyumbang sampah plastik kelaut kedua di dunia. Permasalahan sampah di kota besar, baik itu sampah rumah tangga maupun sampah industri masih menjadi permasaahan pencemaran lingkungan hidup yang semakin serius.

Dampak dari pesatnya pertumbuhan industri serta perubahan pola hidup manusia saat ini, menimbulkan produksi sampah semakin banyak. Hal ini disebabkan karena manusia saat ini, lebih banyak mengkonsumsi bahan makanan yang dibuat oleh industri yang kemudian menyebabkan timbunan limbah padat dan sulit terurai. Limbah yang dihasilkan oleh industri tersebut merupakan sampah plastik, dimana plastik merupakan salah satu wujud konsumsi masyarakat yang serba instan dan praktis. Perkembangan masa sekarang ini, semakin banyak makanan yang dikemas dengan plastik, maka semakin banyak pula dampak yang ditimbulkan dan dapat mengganggu kehidupan manusia itu sendiri (Keraf, 2010).

Berdasarkan Riset dari Dinas Lingkungan Hidup (DLH) di Jakarta terdapat 2.000 ton sampah kantong plastik per tahun nya. Permasalahan yang 


\section{Good governance pengelolaan sampah: komitmen negara terhadap lingkungan hidup \\ Niken Wahyuning Retno Mumpuni, Mustika Prabaningrum Kusumawati}

dihadapi di Negara kita sekarang ini adalah banyak nya timbunan sampah plastik yang dibiarkan begitu saja. Padahal sampah plastik mayoritas banyak yang sulit untuk dikelola. Pemerintah memiliki kewajiban untuk melakukan pengelolaan sampah agar efektif dalam mengatasi permasalahan timbunan sampah. Selain itu untuk mendukung agar dapat berjalan secara efektif, perlu kesadaran masyarakat untuk membantu menyelesaikan permasalahan tersebut. Tumpukan sampah tanpa adanya pengelolaan yang baik menjadikan dampak terhadap lingkungan dan kesehatan warga masyarakat sekitar menjadi korbannya. Konsep pengelolaan sampah 3R (Reduce, Reuse, Recycle) merupakan konsep yang cocok untuk diterapkan di negara berkembang.

Pemerintah Indonesia pada tahun 2009 telah menerbitkan Undang-Undang Republik Indonesia Nomor 32 Tahun 2009 tentang Perlindungan dan Pengelolaan Lingkungan Hidup (untuk selanjutnya disebut dengan UUPPLH). Di dalam UUPPLH telah diatur mengenai asas diman alebih spesifik dalam Pasal 2 (dua) huruf m menyatakan bahwa: "Perlindungan dan Pengelolaan lingkungan hidup dilaksanakan berdasarkan asas tata kelola pemerintahan yang baik."

Terdapat beberapa prinsip-prinsip dasar penyelenggaraan pemerintahan yang baik, yaitu transparansi, partisipasi, dan akuntabilitas. Prinsipprinsip tersebut tidak dapat dilepaskan dari prinsip tata kelola (governance). Untuk menjamin kesejahteraan nasional (national prosperity), prinsip good governance dianggap sebagai bagian yang penting (mongabay.co.id, 2020).

Kaitannya dengan kelembagaan atau susunan organisasi pemerintahan yang mengurusi masalah lingkungan hidup berada pada tingkat pusat, tingkat sektoral dan daerah. Sebagaimana ada di dalam UUPPLH mengenai asas keterpaduan. Pemerintah pusat memiliki kewenangan yang sangat luas untuk menjalankan pemerintahan nya baik dilingkup dalam negeri maupun luar negeri.
Sehingga, dalam menjalankan pola pemerintahan berlaku adanya delegasi kewenangan (delegation of authority) baik antara pemerintah pusat dengan pemerintah daerah (Huda, 2009). Pemerintah dalam pengambilan keputusan atau pembuatan kebijakan serta untuk menciptakan pembangunan yang berkelanjutan, perlu mempertimbangkan kepentingan-kepentingan masyarakat yang erat kaitanya dengan bidang sosial, budaya, ekonomi, politik.

Upaya mewujudkan pembangunan berkelanjutan, maka implementasi prinsip good governance menjadi tuntutan dalam menerapkan kebijakan lingkungan hidup terutama dalam pengelolaan sampah (Yasminingrum, 2017). Artikel ini akan membahas tentang bagaimana konsep pengelolaan sampah dalam bidang lingkungan hidup dikaitkan dengan konteks good governance. Bagaimana implementasi good governance dalam menciptakan kebijakan pengelolaan sampah; Bagaimana pengendalian permasalahan sampah yang ada di lingkup Daerah.

\section{Metode}

Melalui pendekatan yuridis-normatif penelitian ini akan menguraikan serta menganalisis permasalahan sesuai dengan ketentuan peraturan perundang-undangan yang berlaku. Selain itu ditambah dengan bahan-bahan hukum seperti study pustaka dari buku-buku literatur, makalah, artikel, jurnal, hasil penelitian dan serta Kamus Besar Bahasa Indonesia karya ilmiah lainnya yang berhubungan dengan penelitian ini.

\section{Pembahasan}

\subsection{Konsep good governance dalam mencip- takan kebijakan pengelolaan sampah dan plastik sekali pakai}

Sesuai dengan konsep "government", dalam hal pengelolaan yang memiliiki kewenangan tertinggi yaitu Negara dan Pemerintah. Namun 
menurut konsep ini peran pokok untuk menjalankan pemerintahan tidak hanya dibebankan kepada pemerintah saja, tetapi adanya peran masyarakat luas penting untuk menjamin penyelenggaraan Negara. Konsep ini menjadikan beberapa pengertian tentang peran pemerintah, sebagaimana masyarakat memiliki peran yang besar dalam pelaksanaan tugas dan pengawasan terhadap pemerintah. (Widodo, 2001).

Sebagaimana diatur di dalam UU PPLH Nomor 32 tahun 2009 pada Pasal 70 UU PPLH No 32 tahun 2009, menjelaskan tentang ketentuan peran serta masyarakat. Menurut Kusnadi Hardjasumantri dalam buku Penegakan Hukum Lingkungan Indonesia karangan Zairin Harahap, dituliskan mengenai perlunya peran serta masyarakat yang meliputi (Harahap, 2020), yaitu: 1. Memberi informasi kepada pemerintah; 2. Meningkatkan kesediaan masyarakat untuk menerima keputusan; 3. Membantu perlindungan hukum; 3. Mendemokrasikan pengambilan keputusan.

Dalam hubungannya dengan Hukum Tata Lingkungan, mengatur penataan lingkungan guna mencapai keselarasan hubungan antara manusia dan lingkungan hidup, baik lingkungan hidup fisik maupun lingkungan hidup sosial budaya. Bidang garapannya meliputi tata ruang, tata guna tanah, tata cara peran serta masyarakat, tata cara peningkatan upaya pelestarian kemampuan lingkungan, tata cara penumbuhan dan pengembangan kesadaran masyarakat, tata cara perlindungan lingkungan, tata cara ganti kerugian dan pemulihan lingkungan serta penataan keterpaduan pengelolaan lingkungan hidup (Hardjasoemantri, 1999).

The United Development Programme (UNDP) mendefinisikan kepemerintahan (governance) sebagai berikut: Governance is the exercise of economic, political, and administrative authory to manage a country's affairs at all levels and means by which states promote social cohesion, integration, and ensure the well being of their population, (Sedarmayanti, 2004). Apabila dilihat lebih lanjut The United De- velopment Programme (UNDP) menegaskan bahwa "It is complex mechanisms, process, relationships, and institutions trough which citizens and groups articulate their interest, exercise their rights and obligations and mediate their differences"(Widodo, 2001).

Berdasarkan pada pernyataan diatas, lebih lanjut menyebutkan ciri- ciri good governance yaitu (Hetifa, 2003) : 1. Adanya partisipasi masyarakat; 2. Menjamin adanya supremasi hukum. 3. Pemerintah bersifat transparan; 4 . Menerapkan prinsip keadilan; 4. Pemerintah berorientasi pada konsensus untuk mencapai kesepakatan; 5. Pemerintah bertindak secara efektif dan efisien; 6. Segala keputusan dapat dipertanggungjawabkan kepada publik atau bersifat akuntabilitas; 7. Penyelenggaraan pembangunan bervisi strategis. Good governance mimiliki istilah yang populer sejak awal tahun sembilan puluhan, saat ini justru seolah-olah konsepnya menjadi formula yang baru diketemukan dalam upaya suatu negara dapat berjalan secara demokratis. Konsep good governance menggantikan istilah lama yakni good government.

Good governance di dalam suatu penyelenggaraan pemerintahan sebenarnya bukanlah suatu hal yang baru tetapi good governance ini merupakan asas yang berumur telah berabad-abad dan seharusnya menjadi dasar pemerintahan dalam suatu negara demokrasi modern. Yang kemudian menerapkan prinsip-prinsip yang ada di dalam pemerintahan yang baik seperti prinsip partisipasi, transparansi dan akuntabilitas, serta membuka ruang bagi keterlibatan warga masyarakat (Saputra, 2013). Sehingga berdasarkan pendapat ini penting kiranya peran masyarakat dalam pengelolaan lingkungan. Segi functional aspect governance UNDP mendefinisikan sebagai "the exercuse of political, ekonomic, and administrative authorithy to manage a nation's affair at all levels", sehingga governance mempunyai tiga kaki (Nazsir, 2003).

Pelaksanaan prinsip good environmental governance merupakan dukungan pemerintah dan pemerintah daerah agar terselenggara dan tercipta 


\section{Good governance pengelolaan sampah: komitmen negara terhadap lingkungan hidup}

Niken Wabyuning Retno Mumpuni, Mustika Prabaningrum Kusumawati

lingkungan hidup yang baik demi mewujudkan pelaksanaan pembangunan berkelanjutan. Sebagaimana diuraikan dalam bukunya NHT.Siahaan, pengelolaan sampah yang baik merupakan perwujudan dari sistem good governance sebagai upaya mewujudkan good environmental governance (GEG).

Diperlukan kerjasama antara pemerintah daerah dan swasta dalam melakukan upaya pengelolaan lingkungan hidup, hal ini merupakan perwujudan dari prinsip good environmental governance. Lingkungan hidup (environmental) erat kaitannya dengan kondisi biotik sekitarnya dan organism. Sehingga dalam penyelenggaraan tata kepemerintahan yang baik menekankan bentuk keseimbangan interaksi dan keterlibatan antara pemerintah, dunia usaha (swasta), dan masyarakat (civil society), (Faisah \& Prianto, 2015).

Menurut Bruce Mitchell, dkk ada 4 (empat) hal yang penting diperhatikan dalam pengelolaan sumberdaya dan lingkungan yang dapat mendatangkan peluang sekaligus masalah, yaitu: perubahan, kompleksitas, ketidakpastian dan konflik. Selanjutnya dijelaskan bahwa yang dimaksud dengan Perubahan adalah dalam pengelolaan lingkungan hidup harus selalu siap menghadapi perubahan baik perubahan lingkungan itu sendiri maupun perubahan sistem sosial, ekonomi, dan politik yang sering kali mewarnai proses-proses pengambilan keputusan. Kompleksitas, artinya adalah dampak kegiatan manusia terhadap lingkungan sangatlah komplek dan tidak selalu dipahami secara utuh, karena tidak selamanya dampak perubahan dapat diprediksi sebelumnya. Bahkan sebagian dampak perubahan yang terjadi berikut implikasinya tanpa dapat dibayangkan sebelumnya. Ketidakpastian, artinya lingkungan dipenuhi oleh ketidapastian, tidak semua informasi didapat secara komprehensif. Oleh karena itu, dalam proses pengambilan keputusan tidak boleh tergesa-gesa tetapi harus dilakukan dengan hatihati. Konflik, seringkali merfleksikan perbedaan pandangan, ideologi dan harapan. Oleh karena itu, ini merupakan tantangan bagi para pengelola lingkungan (decision maker) untuk dapat mengakomodasikan semua kepentingan itu dengan adil, bijaksana dan dapat diterima semua pihak (Harahap, 2020).

Undang-Undang Nomor 18 Tahun 2008 tentang Pengelolaan Sampah khususnya Pasal 5 sampai Pasal 9 memuat "Peranan pemerintah dan pemerintah daerah dalam menciptakan pengelolaan sampah khususnya berkaitan dengan tugas dan wewenang dalam pemerintahan" (UU Pengelolaan Sampah Nomor 18 Tahun 2008).

Adanya prinsip good environmental governance dapat mendukung peran pemerintah dan pemerintah daerah dalam mengelola sampah dengan menerapkan unsur-unsur seperti: Kedaulatan, Kekuatan, Kebijakan, Pengendalian, Pengembangan, Tanggung jawab (Siahaan, 2009). Unsur-unsur tersebut, penting dalam kerangka good environmental governance (GEG) adanya kriteria prinsip-prinsip good environmental governance seperti prinsip pemberdayaan masyarakat, transparansi, desentralisasi yang demokratis, pengakuan terhadap keterbatasan daya dukung ekosistem dan keberlanjutan, pengakuan hak masyarakat adat dan masyarakat setempat serta kemudian daya penegakan (Nopyandri, 2011).

Berdasarkan pada prinsip-prinsip good environmental governance (GEG) sebagaimana diuraikan diatas yang dapat diwujudkan yakni berkaitan dengan prinsip pemberdayaan masyarakat yang tercantum dalam Pasal 28 Undang-Undang Nomor 18 Tahun 2008 tentang Pengelolaan Sampah. Pasal tersebut membahas mengenai peran masyarakat, antara lain terdapat dalam, Pasal 28 ayat (1) yang menjelaskan bahwa "Masyarakat dapat berperan dalam pengelolaan sampah yang diselenggarakan oleh Pemerintah dan/atau pemerintah daerah". Kemudian Pasal 28 Ayat (2) menjelaskan "Peran dapat dilakukan melalui pemberian usul, pertimbangan, dan saran kepada Pemerintah dan/atau pemerintah daerah, Perumusan kebijakan pengelolaan sampah; dan/atau Pemberian saran dan 
pendapat dalam penyelesaian sengketa persampahan".

Studi perbandingan permasalahan sampah di lingkup daerah, sebagaimana dijelaskan dalam Undang-Undang Nomor 18 Tahun 2008 tentang pengelolaan sampah, terkait dengan pola pengelolaan sampah yang semula kumpul-angkut-buang menjadi pengurangan di sumber dan daur ulang. Dalam Pasal 19 Undang-undang ini juga menjelaskan mengenai "Pengelolaan sampah sebagaimana dibagi menjadi 2 (dua) kegiatan pokok yaitu pengurangan sampah dan penanganan sampah". Dalam aktifitas pengurangan sampah yang sesuai dengan prinsip pengelolaan berwawasan lingkungan dapat dilakukan 3 (tiga) tahapan yang terdiri dari pembatasan penumpukan sampah, daur ulang sampah, dan pemanfaatan kembali sampah.

Permasalahan sampah di Daerah, dalam penulisan ini peneliti mengambil contoh permasalahan sampah di beberapa wilayah terkhusus Daerah Istimewa Yoyakarta. Dimana yang pertama akan dipaparkan terkait dengan permasalahan sampah yang ada di Wilayah Yogyakarta, sebagaimana tergambarkan berdasarkan data tabel sebagaimana berikut ini:

Berdasarkan tabel diatas, terlihat bahwa permasalahan sampah belum menjadi prioritas utama dalam penanggulangannya. Jumla pen- duduk paling banyak ada di wilayah Kabupaten bantul namun sampah yang bisa diolah atau diangkut hanya sebesar 1,91\% sedangkan prosentase terbesar pengelolaan sampah yang dapat terangkut sebesar 34,89 berada di Kota Yogyakarta dengan jumlah penduudk 541.250 pada tahun 2014. Sehingga terlihat penanganan sampah yang dilakukan belum maksimal.

Beberapa ketetuan Pasal di Undang-Undang Nomor 18 tahun 2008 yang mencerminkan prinsip pokok dalam pengelolaan lingkungan, yaitu prinsip-prinsip pencegahan. Penjelasan umum dalam Undang-Undang Nomor 18 tahun 2008 menyatakan: Paradigma pengelolaan sampah yang bertumpu pada pendekatan akhir sudah saatnya ditinggalkan dan diganti dengan paradigma baru pengelolaan sampah. Paradigma baru memandang sampah sebagai sumber daya yang mempunyai nilai ekonomi dan dapat dimanfaatkan, misalnya, untuk energi, kompos, pupuk ataupun untuk bahan baku industri.

Pengelolaan sampah dilakukan dengan pendekatan yang komprehensif dari hulu, sejak sebelum dihasilkan suatu produk yang berpotensi menjadi sampah, sampai ke hilir, yaitu pada fase produk sudah digunakan sehingga menjadi sampah, yang kemudian dikembalikan ke media lingkungan secara aman. Pengelolaan sampah

Tabel 1. permasalahan sampah yang terdapat di Daerah Istimewa Yogyakarta

\begin{tabular}{|c|c|c|c|c|c|c|c|}
\hline Kabupaten & $\begin{array}{c}\text { Jumlah } \\
\text { Penduduk }\end{array}$ & $\begin{array}{l}\text { Volume } \\
\text { Sampah } \\
\left( \pm \mathrm{m}^{3} / \text { hari }\right)\end{array}$ & $\begin{array}{c}\text { Volume sampah } \\
\text { berdasarkan jumlah } \\
\left.\text { penduduk ( } \pm \mathrm{m}^{3} / \mathrm{hari}\right)\end{array}$ & $\begin{array}{c}\text { Penduduk } \\
\text { Terlayani } \\
(\%)\end{array}$ & $\begin{array}{l}\text { Sampah } \\
\text { Terangkat } \\
\left( \pm \mathrm{m}^{3} / \mathrm{har}\right)\end{array}$ & $\begin{array}{l}\text { Sampah } \\
\text { Terang } \\
\text { kut (\%) }\end{array}$ & TPSA \\
\hline Yogyakarta & 541.250 & 320 & 487,125 & 90 & 170 & 34,89 & Piyungan \\
\hline Sleman & 850.176 & $2.917,75$ & $2.125,44$ & 9,6 & 280 & 13,17 & \\
\hline Bantul & 1.020 .363 & $2.550,91$ & $2.550,9075$ & 1,9 & 48,73 & 1,91 & \\
\hline $\begin{array}{l}\text { Kulon } \\
\text { Progo }\end{array}$ & 388.755 & 70 & 971,8875 & 7,2 & 70 & 7,20 & \\
\hline $\begin{array}{l}\text { Gunung } \\
\text { Kidul }\end{array}$ & 424.348 & 334,71 & $1.060,87$ & 17 & 57 & 5,37 & \\
\hline
\end{tabular}

Sumber: Mulasari, dkk., 2014. 


\section{Good governance pengelolaan sampah: komitmen negara terhadap lingkungan hidup}

Niken Wahyuning Retno Mumpuni, Mustika Prabaningrum Kusumawati

dengan paradigma baru tersebut dilakukan dengan kegiatan pengurangan dan penanganan sampah. Pengurangan sampah meliputi kegiatan pembatasan, penggunaan kembali, dan pendauran ulang.

3R di Indonesia terutama digunakan dalam pengelolaan sampah, baik itu sampah oleh industri maupun sampah rumah tangga dengan tujuan untuk mencegah bahaya terhadap kesehatan manusia dan pencemaran lingkungan. 3R dimasukkan untuk menggantikan metode pengelolaan sampah secara konvensional dengan cara membuang sampah pada tempat pengelolaan sampah tanpa ada tindakan lebih lanjut.

Upaya Pengelolaan sampah berbasis masyarakat di Kota Surabaya di lakukan melalui pemberdayaan masyarakat, difasilitasi oleh sektor terkait dan sinkron dengan perencanaan kota. Pengelolaan sampah selain rumah kompos juga adanya Bank Sampah, turunnya volume sampah disebabkan semakin sadarnya warga Kota Pahlawan yang peduli dengan lingkungan. Dengan adanya keterlibatan masyarakat ini sangat jauh menolong, karena mereka sudah memilah, memilih dan mengolah sendiri sampah organik menjadi pupuk kompos, hal ini merupakan bagian dari program pengelolaan sampah berbasis masyarakat. Program ini telah melahirkan sebuah mekanisme penanganan sampah di Kota Surabaya dari hulu ke hilir.

Berdasarkan penelitian terdahulu yang dliakukan oleh Rosita Candrakirana di dalam jurnal Yustisia edisi Sepetember-Desember 2015, Di Kota Surakarta, beberapa usaha yang telah dilakukan untuk pengelolaan sampah ialah dengan adanya bank sampah yang mengubah mindset masyarakat bahwa sampah dapat menghasilkan pendapatan. Sebagai contoh di Kota Surakarta di Kelurahan Mojosongo di RT 05/ RW XVI dipelopori oleh tokoh masyarakat setempat yang memberikan contoh mengenai pengelolaan sampah rumah tangga kepada ibu-ibu rumah tangga yang berada di RT 05/ RW XVI yang mana memisahkan sampah organik maupun sampah non-organik.
Secara Door to Door atau komunal dikumpulkan menjadi satu, untuk sampah Non-Organik, ibuibu rumah tangga mengumpulkannya ke RT setempat selama 7 hari lalu kemudian oleh Ketua RT dikumpulkan kedalam tong besar selama 30 hari. Lalu dijual kepembeli yang telah disepakati berupa non-produk tidak ada pengolahan lebih lanjut dan tetap dalam bentuk aslinya. Namun untuk sampah organik warga telah mampu mengolahnya menjadi produk pupuk organik yang kemudian dijual. Dengan adanya teladan mengenai kesadaran mengelola sampah sehingga masyarakat dapat memanfaatkan sampah menjadi sumber pendapatan. Hal tersebut akhirnya menjadi contoh di kelurahan-kelurahan lain di Kota Surakarta (Candrakirana, 2015).

Pelaksanaan pencegahan untuk penanggulangan penumpukan sampah diatur dalam ketentuan Undang-Undang Nomor 18 tahun 2008 tentang Sampah pada Pasal 14 dan Pasal 15 adalah apa yang dikenal dengan istilah ecolabeling dan ecolabel. Ecolabeling adalah skema pengurus pangan dampak suatu proses dan hasil produksi produkproduk komersial, termasuk cara memberlakukan sampah setelah produk-produk tersebut dikonsumsi (Ida Bagus Wyasa Putra, 2011. Ecolabeling, dengan demikian merupakan rangkaian proses pemilihan bahan baku dan teknologi yang "rendah pencemaran" (low waste tecnology), penyelenggaraan proses produksi dan penghasilan produk-produk yang aman lingkungan, dan penanganan sampah produk setelah dikonsumsi (Putra, 2011).

\subsection{Implementasi good governance dalam menciptakan kebijakan pengelolaan sampah dan plastik sekali pakai di wilayah Daerah Istimewa Yogyakarta}

Penyelenggaraan Pemerintahan yang baik terhadap keberlanjutan lingkungan merupakan penerapan prinsip-prinsip good governance dan good environmental governance. (Nopyandri,2013). Berdasarkan Undang-Undang Nomor 32 Tahun 2004 tentang Pemerintah Daerah Kewenangan 
Pemerintah Daerah menjadi sangat penting untuk melakukan pengelolaan lingkungan dan pelaksanaan pembangunan hal tersebut dikuatkan dalm Pasal 7 ayat (1) yang menyatakan bahwa, "Semua kewenangan dalam bidang pemerintahan adalah kewenangan daerah kecuali kewenangan dalam bidang politik luar negeri, pertahanan keamanan, peradilan, moneter dan fiskal, agama serta kewenangan di bidang ini" (Husin, 2014).

Berkaitan dengan Kewenangan Pemerintah Daerah, maka ada beberapa kebijakan yang telah dibuat di Wilayah Daerah Istimewa Yogyakarta salah satu kebijakan mengenai Pengelolaan sampah diatur didalam Peraturan Daerah Daerah Istimewa Yogyakarta Nomor 3 Tahun 2013 tentang Pengelolaan Sampah Rumah Tangga dan Sampah Sejenis Sampah Rumah Tangga. Penanganan sampah di Daerah Istimewa Yogyakarta harus didasarkan pada Peraturan Perundang-undangan sebagaimana diatur ke dalam Peraturan Daerah Daerah Istimewa Yogyakarta dimana ada lima langkah dalam penanganan sampah, sebagaimana berikut ini dapat ditunjukkan di dalam Pasal 7.

Sebagiamana disebutkan dalam Peraturan Daerah Daerah Istimewa Yogyakarta Nomor 3 Tahun 2013 tentang Pengelolaan Sampah Rumah Tangga dan Sampah Sejenis Sampah Rumah Tangga (Perda DIY Nomor 3 Tahun 2013 tentang Pengelolaan Sampah Rumah Tangga dan Sampah Sejenis Sampah Rumah Tangga), pada Pasal 7 Bab III terkait dengan Pengelolaan, kemudian di dalam Peraturan Daerah Daerah Istimewa Yogyakarta Nomor 3 Tahun 2013 tentang Pengelolaan Sampah Rumah Tangga dan Sampah Sejenis Sampah Rumah Tangga pasal 16 di jelaskan terkait dengan cara penanganan sampah rumah tangga dan sampah sejenis rumah tangga dilakukan dengan cara pemilahan, pengumpulan, pengangkutan, pengolahan,dan pemrosesan akhir sampah.

Pasal 17 menyebutkan "Jenis dan sifat sampah yang harus dibedakan menjadi sampah yang mengandung bahan berbahaya dan beracun, sampah yang mudah terurai, sampah yang dapat digunakan kembali, sampah yang dapat di daur ulang, serta sampah lainya". Kemudian dalam Pasal 18 menyebutkan "Pemilahan sampah sebagaimana dimaksud dalam Pasal 17 harus dilakukan mulai dari sumber sampah, dalam hal masyarakat suatu kawasan belum melakukan pemulihan sampah di sumber sampah, pemilahan dilakukan di TPS 3R atau TPST". Lebh lanjut dalam Pasal 19 menjelaskan bahwa "Setiap orang yang menghasilkan sampah wajib memilah sampah sesuai jenis dan sifatnya".

Selain kebijakan diatas, permasalahan mengenai sampah juga diatur di dalam Keputusan Bersama Bupati Bantul, Bupati Sleman, dan Walikota Yogyakarta Nomor: 152a Tahun 2004, 02/ SKB.KDH/A/2004, 03 Tahun 2001 tentang Kerjasama Pengelolaan Prasarana dan Sarana Perkotaan antar Kabupaten Bantul, Kabupaten Sleman, dan Kota Yogyakarta. Selanjutnya untuk menguatkan pengelolaan secara bersama dari adanya aturan diatas, maka lebih lanjut diatur dalam Perjanjian Kerjasama antar Pemerintah Kota Yogyakarta, Pemerintah Kabupaten Sleman, dan Pemerintah Kabupaten Bantul tentang Pengelolaan Tempat Pengolahan Sampah Terpadu (TPST) di Piyungan Kabupaten Bantul Nomor.01/Perj.YK/2011,2/ PK.KDH/A/2011,03/ Perj/Bt/2011, (Setyaji, 2017).

Regulasi yang diterapkan di Daerah Istimewa Yogyakarta adalah berdasarkan penelitian yang dilakukan oleh Mulasari dkk di dalam jurnal Kesehatan Masyarakat Nasional adalah sebagaimana berikut:

Proses pengelolaan sampah yang ada di Daerah Istimewa Yogyakarta beragam aturannya. Namun telah terdapat badan atau unit yang memiliki kewenangan untuk mengelola sampah tersebut. Harapan dengan adanya pengelolaan sampah tersebut menjadikan lingkungan nyaman dan mendatangkan manfaat ekonomi. Pelayanan publik metode pengawasan dan evaluasi kebijakan pengelolaan sampah belum di bakukan tetapi telah memenuhi tanggungjawabnya dalam pelayanan publik (Asti, 2014). 
Good governance pengelolaan sampah: komitmen negara terhadap lingkungan hidup

Niken Wabyuning Retno Mumpuni, Mustika Prabaningrum Kusumawati

Tabel.2. Regulasi tentang penanganan sampah di DIY

\begin{tabular}{|c|c|c|c|c|c|}
\hline Kabupaten & $\begin{array}{c}\text { Unit } \\
\text { Pelaksana } \\
\end{array}$ & Pengaturan & $\begin{array}{c}\text { Program } \\
\text { Kebijakan }\end{array}$ & Proyek & Insentif \\
\hline Yogyakarta & $\begin{array}{l}\text { Badan } \\
\text { Lingkung } \\
\text { an Hidup }\end{array}$ & $\begin{array}{l}\text { Undang-Undang } \\
\text { No.18 Tahun2008 } \\
\text { PerdaKota } \\
\text { Yogyakarta No. } 18 \\
\text { Tahun } \\
2002\end{array}$ & $\begin{array}{l}\text { Pengump ulan } \\
\text { danPengangk } \\
\text { utan Sampah }\end{array}$ & $\begin{array}{l}\text { Komposing, daur } \\
\text { ulangplastik, bank } \\
\text { sampah, faskel, } \\
\text { jejringpengepul } \\
\text { Kota } \\
\text { Yogyakarta }\end{array}$ & $\begin{array}{l}\text { Dana stimulan } 2 \\
\text { juta, lombadengan } \\
\text { pemenang Rp. } 15 \\
\text { juta, }\end{array}$ \\
\hline Bantul & $\begin{array}{l}\text { Badan } \\
\text { Lingkungan } \\
\text { Hidup, } \\
\text { Dinas } \\
\text { Pekerjaan } \\
\text { Umum }\end{array}$ & $\begin{array}{l}\text { Undang-Undang } \\
\text { No. } \\
18 \text { Tahun2008, } \\
\text { PermendagriNo } 33 \\
\text { Tahun2010, Perda } \\
\text { Kabupaten Bantul } \\
\text { No.15 Tahun } 2011\end{array}$ & $\begin{array}{l}\text { Pengump } \\
\text { ulan dan } \\
\text { pengangk } \\
\text { utan sampah, } \\
\text { jejaring } \\
\text { pengelola an } \\
\text { sampah } \\
\text { mandiri }\end{array}$ & $\begin{array}{l}\text { Pengomposa n, } \\
\text { banksampah, 3R, } \\
\text { jejering pengelola } \\
\text { sampah mandiri }\end{array}$ & $\begin{array}{l}\text { Gerobak, tong } \\
\text { sampah, } \\
\text { komposer, mesin } \\
\text { jahit, cacah } \\
\text { sampah plastik, } \\
\text { mengikutsertaka n } \\
\text { komunitas para } \\
\text { kompetisi tingkat } \\
\text { nasional }\end{array}$ \\
\hline$\overline{\text { Sleman }}$ & KLH & $\begin{array}{l}\text { Perda Kabupaten } \\
\text { Sleman No } \\
14 \text { Tahun2007, } \\
\text { PerdaKabuoaten } \\
\text { Sleman No } \\
13 \text { Tahun } \\
2011\end{array}$ & $\begin{array}{l}\text { Pengump ulan } \\
\text { danpengangk } \\
\text { utan sampah }\end{array}$ & $\begin{array}{l}\text { Pengomposa } \mathrm{n} \\
\text { daur ulangdan } \\
\text { daerahswakelola } \\
\text { sampah }\end{array}$ & $\begin{array}{l}\text { Reward } \\
\text { perlombaan, } \\
\text { keringanan } \\
\text { retribusi untuk } \\
\text { pengurangan B3 } \\
\text { rumah tangga. }\end{array}$ \\
\hline KulonProgo & $\begin{array}{l}\text { Dinas PUoleh } \\
\text { UPTD } \\
\text { kebersihan } \\
\text { dan } \\
\text { pertanam } \\
\text { an, DInas } \\
\text { KLH }\end{array}$ & $\begin{array}{l}\text { UU No. } 18 \\
\text { Tahun 2008, } \\
\text { UU No 32 } \\
\text { Tahun 2009,Perda } \\
\text { Kabupaten Daerah } \\
\text { Tingkat II No08 } \\
\text { Tahun } \\
\text { 1991, } \\
\text { Peraturan Bupati } \\
\text { KulonProgo No } 17 \\
\text { Tahun 2005, } \\
\text { Instruksi Bupati } \\
\text { KP No 03 } \\
\text { Tahun } 2010 \\
\end{array}$ & $\begin{array}{l}\text { Pengump } \\
\text { ulan dan } \\
\text { pengangk } \\
\text { utan sampah, } \\
\text { mobil hijau }\end{array}$ & $\begin{array}{l}\text { Mobil hijauKLH, } \\
\text { 3R, } \\
\text { dan kegiatan } \\
\text { pemilahan sampah }\end{array}$ & $\begin{array}{l}\text { Penghargaan } \\
\text { terhadap } \\
\text { program } \\
\text { pengelolaan } \\
\text { sampah }\end{array}$ \\
\hline $\begin{array}{l}\text { Gunung } \\
\text { kidul }\end{array}$ & $\begin{array}{l}\text { DPU UPT } \\
\text { Kebersihan } \\
\text { dan } \\
\text { Pertanaman }\end{array}$ & $\begin{array}{l}\text { UU No } 18 \\
\text { Tahun } 2008\end{array}$ & $\begin{array}{l}\text { Pengump } \\
\text { ulan dan } \\
\text { pnegngkutan } \\
\text { sampah }\end{array}$ & $\begin{array}{l}\text { Program peran } \\
\text { sertamasyarakat, } \\
\text { yaitu penyuluhan, } \\
\text { pembinaan, } \\
\text { pelatihan, } \\
\text { penyediaan sarana } \\
\text { prasarana, gotong } \\
\text { royong, dan } \\
3 \mathrm{R}\end{array}$ & $\begin{array}{l}\text { Pemberian sarana } \\
\text { dan prasarana }\end{array}$ \\
\hline
\end{tabular}

Sumber : Mulasari, dkk., 2014. 


\section{Jurnal Cakrawala Hukum, Volume 12 No. 1 April 2021}

ISSN PRINT 2356-4962 ISSN ONLINE 2598-6538

\section{Simpulan}

Good Governance merupakan suau gerakan atau upaya untuk mewujudkan pemerintahan yang baik. Upaya yang memiliki tujuan dan rencana strategis yang jelas mengenai segala sesuatu ataupun usaha yang dijalankan agar sasaran dapat tercapai. Pelaksanaan prinsip good environmental governance dalam pengelolaan sampah di lingkup Nasional maupun Daerah perlu pelibatan masyarakat dan media informasi serta prinsip transparasi dan memilki inisiatif dalam memberikan informasi kepada masyarakat tanpa harus diminta terlebih dahulu. Adapun mengenai daya paksa untuk penegakan hukumnya, perlu adanya pemberian sanksi, baik sanksi administrasi maupun sanksi pidana karena selama ini yang ada masih belum bisa maksimal dalam penegakannya. Perlu adanya sinergitas antar lembaga dalam menjalankan kebijakan yang telah di buat. Kemudian untuk upaya pencegahan mewajibkan produsen dan melakukan sosialisasi untuk menambahkan zat adiktif dalam memproduksi kantong plastik, sehingga menghasilkan kantong plastik ramah lingkungan. Serta sampah dapat terurai dengan baik.

\section{DaftarPustaka}

Abdullah. Kasman. 2002. Penyelenggaraan Pemerintahan Dalam Konsep Good Governance. Jurnal Meritokrasi, Vol. 1 No. 1. Fakultas Hukum Universitas Hasanuddin. Makassar.

Arisaputra, Muhammad Ilham. 2013. Penerapan Prinsipprinsip Good Governance Dalam Penyelenggaraan Reforma Agraria di Indonesia. Jurnal Yuridika, Vol.28 No. 2, Mei-Agustus.

Artikel Kementerian Lingkungan Hidup dan Pengurus Besar Nahdatul Ulama. 2020. Tingkatan Taqwa melalui Kepedulian Lingkungan (Peduli Lingkungan Dalam Perspektif Islam. Jakarta.

Asti, Surahma. Dkk. 2011. Kebijakan Pemerintah dalam Pengelolaan Sampah Domestik. Jurnal Kesehatan Masyarakat Nasional Vol. 8, No 8, Mei.
Candrakirana, Rosita. 2015. Penegakan Hukum Lingkungan Dalam BidangPengelolaan Sampah Sebagai Perwujudan Prinsip Good Environmental Governance di Kota Surakarta. Jurnal Yustisia, Vol.4 No3 September-Desember.

Efendi, A'an. 2014. Hukum Lingkungan "Instrumen Ekonomik dan Pengelolaan Lingkungan di Indonesia dan Perbandingan dengan Beberapa Negara. Citra Aditya Bakti. Bandung.

Faisah, Nur \& Prianto, Andi Luhur. 2015. Good Environmental Governance (Studi Kasus Pengelolaan Taman Macan Di Kota Makassar). Jurnal Otoritas, Volume V No. 2 Oktober.

Hadjon, Philipus M. 2004. Tolak Ukur Keabsahan Tindak Pemerintahan Dan Keputusan Tata Usaha Negara. Makalah, Disampaikan pada penyelenggaraan House Legal Training Hukum Administrasi dan PTUN pegawai BI. tanggal 19-29 Juli.

Hadjon, Philipus M. et.al. 2012. Hukum Administrasi dan Good Governance. Universitas Trisakti. Jakarta.

Hadjon, Philipus M. et.al. 2012. Hukum Administrasi dan Good Governance. Universitas Trisakti. Jakarta.

Harahap, Zairin. 2020. Penegakan Hukum Lingkungan Indonesia. FH UII Press. Yogyakarta.

Hardjasoemantri, Koesnadi. 1999. Hukum Tata Lingkungan. Gadjah Mada University Press. Yogyakarta.

Hetifa, Sumarto Sj. 2003. Inovasi, Partisipasi dan Good Governance. Yayasan Obor Indonesia. Bandung.

Huda, Ni'matul. 2009. Hukum Pemerintahan Daerah. Nusa Media. Bandung.

Husin, Sukanda. 2014. Penegakan Hukum Lingkungan Indonesia. Sinar Grafika. Jakarta.

Islamy, M. Irfan. 2000. Prinsip-Prinsip Perumusan Kebijaksanaan Negara. Bumi Aksara. Jakarta.

Keraf, A Sonny. 2010. Krisis dan Bencana Lingkungan Hidup Global. Kanisius. Yogyakarta.

Mulasari, Asti., dkk. 2016. Analisis Situasi Permasalahan Sampah Kota Yogyakarta dan Kebijakan Penanggulangannya, Jurnal Kesehatan Masyarakat, Vol II No 2. 


\section{Good governance pengelolaan sampah: komitmen negara terhadap lingkungan hidup}

Niken Wabyuning Retno Mumpuni, Mustika Prabaningrum Kusumawati

Mulasari, dkk. 2014. Pemerintah Dalam Pengelolaan Sampah Domestik. Jurnal Kesehatan Masyarakat Nasional, Vol. 8 Mei.

Nazsir, Nasrullah. 2003 Good Governance. Jurnal Mediator, Volume 4 No. 1.

Nopyandri. 2009. Penerapan Prinsip Good Environmental Governance dalam Perda Kabupaten Sleman Provinsi Daerah Istimewa Yogyakarta. Jurnal Ilmu Hukum, Volume 2 No. 1.

Peraturan Daerah Daerah Istimewa Yogyakarta Nomor 3 Tahun 2013 tentang Pengelolaan Sampah Rumah Tangga dan Sampah Sejenis Sampah Rumah Tangga.

Putra, Ida Bagus Wyasa. 2011. Hukum Lingkungan Internasional Perspektif Bisnis Internasional. Refika Aditama. Bandung.

Rosyada, Dede. Dkk. 2000. Demokrasi, Hak Asasi Manusia Dan Masyarakat Madani. ICCE UIN Syarif Hidayatullah. Jakarta.

Sedarmayanti. 2004. Good Governance (Kepemerintahan Yang Baik), Bagian Kedua. Mandar Maju. Bandung.

Setyaji, Wisangititis. 2017. Pengelolaan Sampah TPST Piyungan: Potret Kondisi Persampahan Kota
Yogyakarta, Kabupaten Bantul, dan Kabupaten Sleman. Departemen Geografi Lingkungan Fakultas Geografi Universitas Gadjah Mada. Yogjakarta.

Siahaan, NHT. 2011. Hukum Lingkungan, Pancuran Alam. Jakarta.

Undang-Undang Republik Indonesia Nomor 32 Tahun 2004 tentang Pemerintah Daerah.

Undang-Undang Republik Indonesia Nomor 32 tahun 2009 tentang Perlindungan dan Pengelolaan Lingkungan Hidup.

Undang-Undang Republik Indonesia Nomor 8 tahun 2008 tentang Pengelolaan Sampah.

Widodo, Joko. 2001. Good Governance: Telaah dari Dimensi Akuntabilitas, Kontrol Birokrasi pada Era Desentralisasi dan Otonomi Daerah. Insan Cendekia. Surabaya.

Yasminingrum. 2017. Kebijakan Lingkungan Dalam Konteks Good Governance, Jurnal Ilmiah Dunia Hukum, Vol 13 No 1 Oktober. 4. 